\title{
An Unusual Endoscopic Approach to Perform a Percutaneous Endoscopic Gastrostomy
}

\author{
Oricchio $\mathbf{M}^{1 *}$, Taullard $\mathrm{A}^{1}$, Álvarez $\mathrm{D}^{2}$ and Munyo $\mathrm{A}^{2}$ \\ ${ }^{1}$ Clínica de Gastroenterología, Uruguay \\ ${ }^{2}$ Cátedra de Otorrinolaringología, Uruguay
}

Submission: April 10, 2020; Published: June 10, 2020

*Corresponding author: Martín Oricchio, Clínica de Gastroenterología, Hospital de Clíncias, Montevideo, Uruguay

\begin{abstract}
Percutaneous endoscopic gastrostomy is a route of feeding and nutritional support in patients with a functional gastrointestinal system who require long-term enteral nutrition. The main indications for this procedure include neurological diseases and cancer of the upper airdigestive tract. There are some patients in whom endoscopy is not feasible because of esophageal stricture or other anatomic obstacles. In these cases, gastrostomy tube may be placed radiologically or by surgery. We present the case of a 60 -year-old man who received radiotherapy due to a poorly differentiated squamous carcinoma. Total laryngectomy was performed because of cancer recurrence one year later, and it presented a pharyngocutaneous fistula as a postoperative complication. He was referred for percutaneous endoscopic gastrostomy but it was not possible to access esophagus through oral cavity in the gastroscopy, so an unusual endoscopy approach accessing the esophagus through the pharyngocutaneous fistula was performed.

Keywords: Percutaneous endoscopic gastrostomy; Pharyngocutaneous fistula; Gastrostomy tube; Hemorrhage
\end{abstract}

\section{Introduction}

Percutaneous endoscopic gastrostomy (PEG) is an effective and safe method of nutritional support in patients who require enteral nutrition for more than 30 days [1]. PEG was first described in 1980 by Ponsky and Gauderer as a less invasive alternative than surgical gastrostomy [2]. The main indications include neurological disorders, oropharyngeal and esophageal neoplasms [3].

For the placement of a gastrostomy tube, the "pull" method is the most widely used technique, since it has less technical difficulty and a lower complication rate in comparison with other techniques [1]. It is considered a safe technique and its complications can be divided into minors and majors [3]. The minors correspond to leak around the stoma, removal of the catheter by the patient, and infection of the stoma [4-6]. Hemorrhage, severe infection with necrotizing fasciitis, and damage to other organs are considered major complications that occur infrequently [7-9].

In the case of patients with head and neck cancers in whom the passage of the endoscope fails, radiological or surgical routes are considered as alternative techniques [10].

\section{Case Report}

A 60-year-old man and former smoker presented with dysphonia and stridor over a period of 3 months. A diagnosis of poorly differentiated squamous carcinoma was performed and was treated with radiotherapy. Due to tumor recurrence one year later, total laryngectomy was performed with pharyngocutaneous fistula as a complication (Figure 1). He was referred to the endoscopy unit for PEG. In a first attempt, it was not possible to access the esophagus through the oral cavity in the gastroscopy. In order to avoid surgical gastrostomy, an endoscopic gastrostomy was performed in a second attempt by directly accessing the esophagus through the pharyngocutaneous fistula (Figure 2).

\section{Discussion}

There are few absolute contraindications to PEG placement, and these mainly include technical limitations as a result of anatomical particularities such as lack of transillumination with an inability to access the anterior gastric wall, including colonic interposition and severe ascites, morbid obesity and uncorrectable 
advanced coagulopathy $[1,3]$. The presence of oropharyngeal or esophageal strictures that hinder the passage of conventional endoscopes are considered relative contraindications, as well as pharyngeal or esophageal neoplasms [3]. Some studies have shown clinical benefit in placing prophylactic PEG in patients with head and neck cancer $[11,12]$.

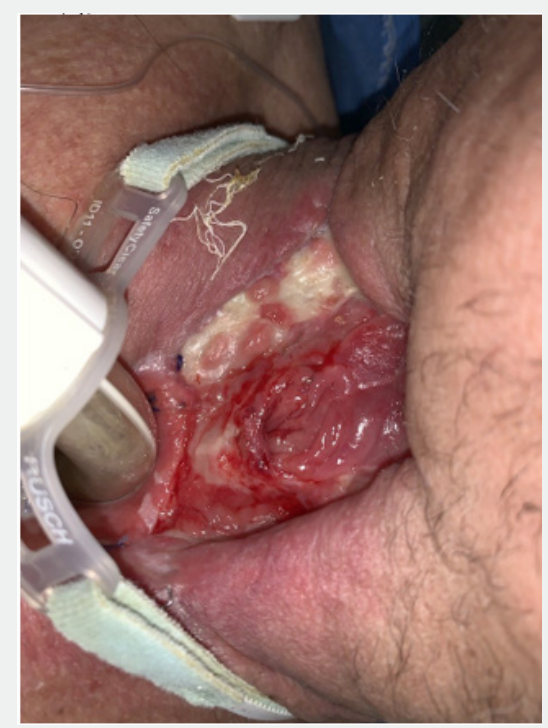

Figure 1: Pharyngocutaneous fistula.

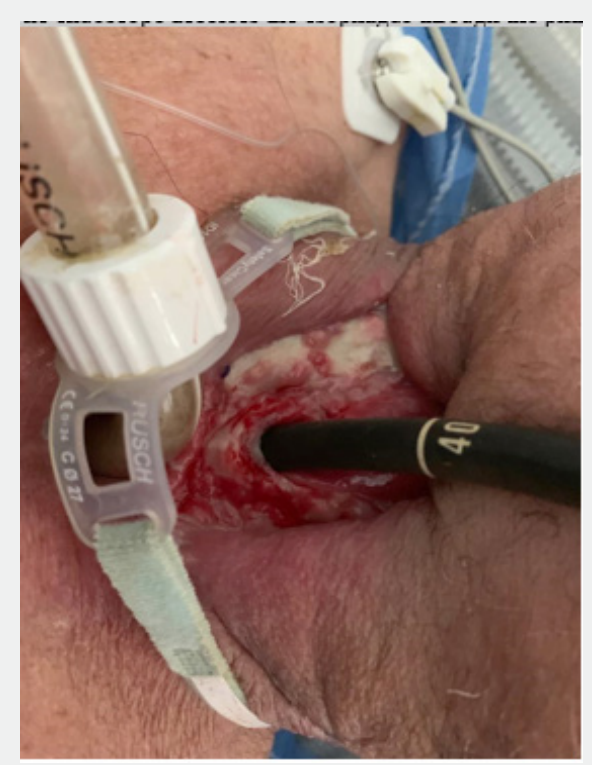

Figure 2: The endoscope accesses the esophagus through the pharyngocutaneous fistula.

PEG has a lower rate of minor complications compared to surgical gastrostomy, along with a shorter time to perform it [13]. In addition, surgical gastrostomy is a more invasive procedure, with a longer recovery period and more expensive $[13,14]$. The radiologically inserted gastrostomy (RIG) is another option in patients with obstructing head and neck or esophageal carcinomas $[3,10]$. An Australian study showed that although both PEG and RIG insertion techniques compare favorably in terms of the majority of peri and post procedural complications, the rates of tube dislodgement were significantly higher in the RIG group [15]. To the best of our knowledge, few cases where reported that accessed the esophagus through the pharyngocutaneous fistula as in this case [16-18].

\section{Conclusions}

Gastrostomy tubes may be placed endoscopically, radiologically, or by surgery. The endoscopic approach is less invasive, but in some circumstances is not feasible because of 
esophageal stricture or other anatomic obstacles. In this case, a rare and unusual endoscopy approach accessing the esophagus through the pharyngocutaneous fistula was performed.

\section{References}

1. Lucendo AJ, Friginal-Ruiz AB (2014) Percutaneous endoscopic gastrostomy: an update on its indications, management, complications, and care. Rev Esp Enferm Dig 106(8): 529-539.

2. Ponsky JL, Gauderer MW (1981) Percutaneous endoscopic gastrostomy: a nonoperative technique for feeding gastrostomy. Gastrointest Endosc 27(1): 9-11.

3. Molina Villalba C, Vázquez Rodríguez JA, Gallardo Sánchez F (2019) Percutaneous endoscopic gastrostomy. Indications, care and complications. Med Clin (Barc) 152(6): 229-236.

4. Vanis N, Saray A, Gornjakovic S, Mesihovic R (2012) Percutaneous endoscopic gastrostomy (PEG): Retrospective analysis of a 7-year clinical experience. Acta Inform Med 20(4): 235-237.

5. Schrag SP, Sharma R, Jaik NP, Seamon MJ, Lukaszczyk JJ, et al. (2007) Complications related to percutaneous endoscopic gastrostomy (PEG) tubes. A comprehensive clinical review. J Gastrointestin Liver Dis 16(4): 407-418.

6. Rosenberger LH, Newhook T, Schirmer B, Sawyer RG (2011) Late accidental dislodgement of percutaneous endoscopic gastrostomy tube: an underestimated burden on patients and the health care system. Surg Endosc 25: 3307-3311.

7. Hucl T, Spicak J (2016) Complications of percutaneous endoscopic gastrostomy. Best Pract Res Clin Gastroenterol 30(5): 769-781.

8. Cave DR, Robinson WR, Brotschi EA (1986) Necrotizing fascitis following percutaneous endoscopic gastrostomy. Gastrointest Endosc 32(4): 294-296

9. Rahnemaiazar AA, Naghshizadian R, Kurtz A, Farkas DT (2014) Percutaneous endoscopic gastrostomy: indications, technique, complications and management. World J Gastroenterol 20(24): 77397751.
10. Pickhardt PJ, Rohrmann CA Jr, Cossentino MJ (2002) Stomal metastases complicating percutaneous endoscopic gastrostomy: CT findings and the argument for radiologic tube placement. Am J Roentgenol 179(3): 735-739.

11. Pulkkinen J, Rekola J, Asanti M, Grénman R (2014) Prophylactic percutaneous endoscopic gastrostomy in head and neck cancer patients: results of tertiary institute. Eur Arch Otorhinolaryngol 271(6): 1755-1758.

12. Locker JL, Bonner JA, Carroll WR, Caudell JJ, Keith JN, et al. (2011) Prophylactic percutaneous endoscopic gastrostomy tube placement in treatment of head and neck cancer: a comprehensive review and call for evidence-based medicine. J Parent Enteral Nutr 35(3): 365-374.

13. Pereira Bravo JC, Ide E, Kondo A, Hourneaux de Moura DT, Hourneaux de Moura ET, et al. (2016) Percutaneous endoscopic vs surgical gastrostomy in patients with benign and malignant diseases: a systematic review and meta-analysis. Clinics (Sao Paulo) 7(3): 169178.

14. Jones M, Santanello SA, Falcone RE (1990) Percutaneous endoscopic vs surgical gastrostomy. J Paretera Enteral Nutr 14(5): 533-534.

15. Vidhya C, Phoebe D, Dhina C, Jayne S, Robert F (2018) Percutaneous endoscopic gastrostomy (PEG) versus radiologically inserted gastrostomy (RIG): A comparison of outcomes at an Australian teaching hospital. Clin Nutr ESPEN 23: 136-140.

16. Di Palma LDV, Mello GFSE, Granados SL, Glória RD, Dalbem CS, et al. (2017) Pharyngocutaneous fistula as an alternative access route for inserting a percutaneous endoscopic gastrostomy tube in head and neck cancer patients. Endosc Int Open 5(7): E630-E634.

17. Lujber L, Fábián J, Pytel J (2001) Inserting a percutaneous endoscopic gastrostomy tube via a cervical fistula formed after major surgery on a patient with a head and neck tumor. Surg Laparosc Endosc Percutan Tech 11(5): 327-329.

18. Lujber L (2006) Placement of a percutaneous endoscopic gastrostomy feeding tube via a cervical pharyngocutaneous fistula. Endoscopy 38(Suppl 2): E57.

\section{Your next submission with JuniperPublishers} will reach you the below assets

- Quality Editorial service

- Swift Peer Review

- Reprints availability

- E-prints Service

- Manuscript Podcast for convenient understanding

- Global attainment for your research

- Manuscript accessibility in different formats

( Pdf, E-pub, Full Text, audio)

- Unceasing customer service

Track the below URL for one-step submission https://juniperpublishers.com/online-submission.php 